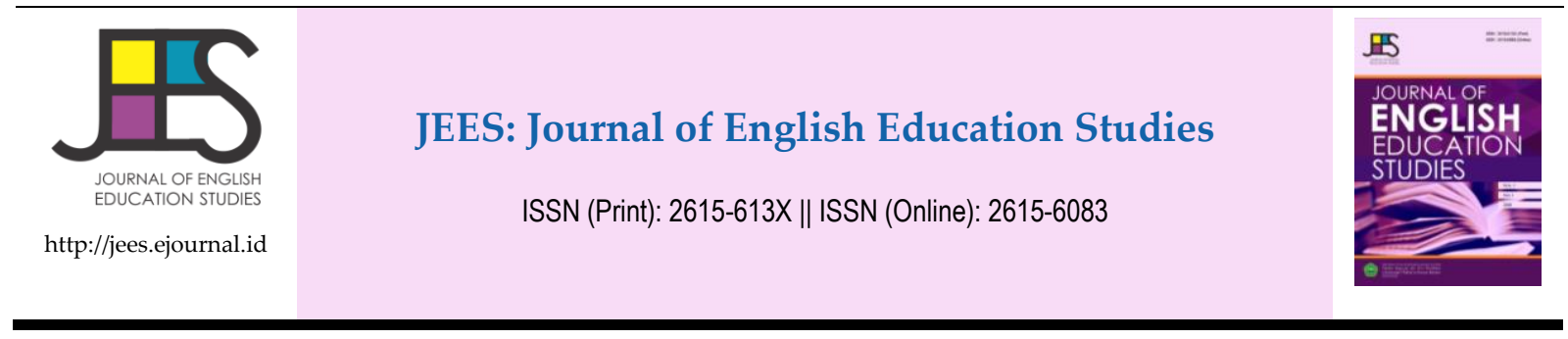

\title{
The Impacts of Students' Reading Habit and Their Language Attitudes toward Reading Comprehension
}

\author{
Ari Fajria Novari ${ }^{1}$ \\ ${ }^{1}$ English Education Study Program, Teacher Training and Education Faculty of Universitas Mathla'ul Anwar Banten

\section{ARTICLE INFO} \\ Keywords: \\ Reading Habit \\ Language Attitudes \\ Reading Comprehension

\begin{abstract}
This research is aimed as follows: to get empirical data and analyze the impacts of reading habit and language attitudes towards students' reading comprehension at private Senior High School in Pandeglang, Banten Province. This research is done by statistics, Kolmogorov-Smirnov test, to test the normality, and Anova Table. The research was held at Private Senior High School in Pandeglang. Data was collected by giving instruments for reading habit (questionnaire/16 items), language attitude (questionnaire/16 items) to eleven grade students at Madrsasah Aliyah Mathla'ul Anwar, MAN 1 Pandeglang, and SMA Mathla'ul Anwar Menes. Due to the result, it can be inferred that there is an impact of reading habit towards students' reading comprehension (Sig. $=0.000$ and t_test $=14.648$; while $t_{-}($table $=)$1.669). There is an impact of language attitude towards students' reading comprehension (Sig. $=0.040$ and $t$ test $=0.846$; while $\left.t \_(t a b l e=) 1.669\right)$. There are impacts of reading habit and language attitudes toward students' reading comprehension, the score of Sig. $=0.000<0.05$ and F_test $=160.024$; while F_table $=3.148$, so H_o is rejected, it means
\end{abstract} \\ that the regression coefficient is significant.
}

This is an open access article distributed under the terms of the Creative Commons Attribution 4.0 International License, which permits unrestricted use, distribution, and reproduction in any medium, provided the original work is properly cited. (c) 2018 Ari Fajria Novari.

\section{INTRODUCTION}

Reading is very important skill both in our life generally and in language learning particularly. It also facilitates us to gain access to science in various field of study and to sense of others' felling, attitude or behaviors and to know what happened in the past or what may happen in the future. Reading is one of communicative skills which should be mastered by Senior High School students, including students of Madrasah Aliyah (Private Senior High Schools, henceforth MA). Indeed, reading is essential for students in order to get access to the language of text and crucial as a source of comprehensible input to accelerate students' academic growth, as stated by Grabe and Stoller (2001: 3), that academic success depends on students comprehending the language of texts. Further they explain that reading also provides the foundation for synthesis and critical evaluation skills and it is the primary means for independent learning, whether the goal is performing better on academic tasks, learning more about subject matters, or improving language abilities.

Not only for academic success, but this skill is also important in order to be successful in other aspects of life. It is due to the fact that as a society becomes more complex and industrialized, along

\footnotetext{
${ }^{1}$ Corresponding author's address: English Education Study Program of Teacher Training and Education Faculty, Universitas Mathla'ul Anwar, Banten, Indonesia e-mail: ari.fajria@gmail.com
} 
with the advances of technology, more occupations require high levels of education or specialized training in which good reading ability is vital. In addition, it is also important to everyday functioning, such as reading newspapers, street signs, announcements or pamphlets found in every corner of our neighborhood. Those who cannot read well are at a disadvantage (Harris and Sipay, 1980: 15). Hence, reading ability increases in importance.

Selecting appropriate materials will help students a lot in improving their reading competences. It has been proved that meaningful conceptual content in reading instruction increases reading and then comprehension as the students' interest and positive attitude toward reading are increased (Wallace, 1992: 75; Alderson, 2003: 116). Another finding shows that students who were provided choice of text also performed higher on reading tasks than those with no choice (Brantmeier, 2006: 34).

A research by Alexander 1997, (Brantmeier, 2006: 45) also proves that personal interest is connected to the students' background knowledge or existing schema. Students with little domain or topic knowledge and who are generally uninterested in the domain and in the passages perform lower than their counterparts on a written recall task. It is revealed that a positive relationship exists between personal interest, prior knowledge, and comprehension.

In context of MA, where all of the students are Muslim, the findings above can be applied by adapting or modifying general reading texts found in many available textbooks into Islamic reading texts, i.e. reading texts which explicitly reflect Islamic values and community cultural entities (Argungu, 1996: 12).

This is important for some reasons. The first is that as a matter of fact, cultural issues remain the most important aspects of English Language Teaching (ELT) problems to watch in Muslim educational institutions (Argungu, 1996: 13). According to Richards (2002: 32), the cultural values of Britain and the United States are often seen as irrelevant to language teaching, expect in situations where the learner has a pragmatic need for such information. He argues that although English is still promoted as a tool that will assist with educational and economic advancement, in many parts of the world, it is viewed as one that can be acquired without any cultural trappings that go with it. Thus, morality, culture and even ideology are said to play important roles in motivating students' learning of ELT materials.

The second reason for discussing Islamic Values in ELT materials is that to make students aware that in Islam, learning languages is regarded as rewarding act and hence, it is encouraged: "And among His signs is the creation of the heavens and the earth and variation in your language and your colors: verily in that signs for those that know" (Qur'an, Ar Rum: 22). Moreover, reading is the first command from Allah (SWT) for Muslim (Qur'an, Al 'Alaq: 1). By learning other languages, muslims can arrive at an understanding of the skills and achievements of others (Hare, 1996: 124) and thus, muslims can acquire skills which will be beneficial to the Islamic community. Additionally, it will enable muslims to convey the message to the spikers of the language they learn. The awareness of these, when exposed to and discussed with the students, may motivate them in learning English.

The third reason is that for students, learning English is more an obligatory rather than for their own interests (Cahyono and Widiati, 2004: 40). And this is a common phenomenon that only a small number of students learning English as second or foreign language get sense of intrinsic satisfaction from the learning. Consequently, the teacher's role is needed to maintain and increase the interest of the students to result in effective learning, by giving attention to the factors influence it, such as the subject matter and the student's perception of its usefulness. The use of Islamic reading texts is assumed to be helpful in increasing students' interest, as the texts are familiar to and connected with their background knowledge and experiences, as claimed by proponents of Contextual Teaching and Learning (Johnson, 2007: 8; see also Alexander, 1988: 86; Wallace, 1992: 77; Alderson, 2003: 411). 
Based on researcher's own teaching experiences, it seems that students of Madrasah Aliyah are more engaged and interested in the activities of learning English when they are presented with English texts related with their own life, and their Islamic knowledge (i.e. especially those they have learnt from Islamic subject matter such as Qur'an Hadists, Aqidah Akhlaq and Fiqih). This phenomenon is interesting to be proved whether this approach really works well in helping the students learning English. Hence, this study tries to investigate it, especially the effect of using Islamic reading texts in improving students' reading comprehension, students' attitudes toward Islamic and general reading texts, and the significance of students' attitudes toward the texts to their reading comprehension.

There are many definitions of reading, a simple but compact definition given by Harris and Sipay (1980: 8) states that, "Reading is the meaningful interpretation of printed or written verbal symbols". Further they explain that it is a complex process in which the recognition and comprehension of written symbols are influenced by readers' perceptual skills, decoding skills, experiences, language backgrounds, mind sets, and reasoning abilities as they anticipate meaning on the basis of what has been read. Meanwhile, the definition of reading comprehension is implicit within most definitions of reading (Carnine, Silbert, \& Kameenui, 1990: 275 in Brown, 2005).

Reading becomes a habit is not an easy one. It needs long process, some exercise and a strong motivation from the reader to make reading as a habit. If reading is a habit, a student would like to get into of course there are number of ways to cultivate it. The student will realize that reading is highly enjoyable if he or she reads his or her interest.

As has been stated previously, most students in Indonesia are not interested in learning English (Cahyono and Widiati, 2004) and the result is the English teaching in this country has largely failed, and more particularly so in areas outside the island of Java (Jazadi, 2003). Similarly, Richards (1992) contends that as some language teaching textbooks continue to be teacher-oriented, planned in terms of "items" and "teaching points", teachers are faced with the problem of students' lack of motivation. Hence, reading texts which students can relate to their personal histories or their understanding of the world and relevant to their needs and interest improve their comprehension (Goodman, Y., 1976). Furthermore, the text can generate the motivation to keep on reading. Indeed, a significant body of research argues that motivation has an important impact on reading development (Hutchinson and Waters, 2001; Grabe and Stoller, 2001).

This fact is supported also by Grabe and Stoller (2001) argue that the precious experience with reading and their perception about usefulness of reading are often linked with students' attitude about reading. These attitudes influence students' willingness to involve themselves in reading lessons and related activities (Alderson, 2003).

In general, attitude is a prediction to behave in a particular way (Procter, 2001). Specifically related to language, it is defined as expressions of positive or negative feelings towards a language which may reflect impression of linguistic difficulty or simplicity, ease or difficulty of learning, degree of importance, elegance, social status, etc. (Richards et al., 1992). Meanwhile, specific to reading attitudes have been defined as "a system of feelings related to reading that causes the learner to approach or avoid a reading situation" (Alexander, 1998: 386).

Further, it is proposed that attitude consists of three components: cognitive, affective and behavioral. The cognitive component refers to beliefs, information, and perceptions about reading act. The affective component, affected by the cognitive component, is concerned with the students' evaluation of how they feel (emotional reactions) about reading, while the behavioral refers to the student's intention or action in relationship to their beliefs and feelings (see also Iskandarwassid and Sunendar, 2008). 


\section{METHOD}

It is a fact that in research we have to use a method. The method that will be used in this research is explanatory survey. This method pointed out on the determination of information about variable not about the information by using multiple choice test for the reading habit and students' attitudes, and a reading comprehension test. So, the relation design that is becoming the correlation in this research is:

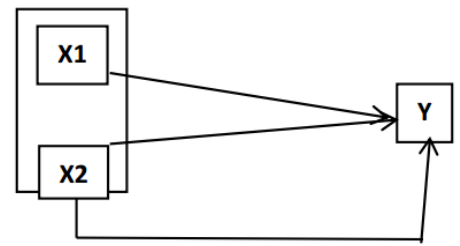

\section{Picture 1. Diagram of Research Design}

Where: X1 is Reading Habit

$\mathrm{X} 2$ is Language Attitude

$\mathrm{Y}$ is Reading Comprehension

The source of the data is from reading habit and attitudes variable, the answer of respondents (students) of all the questions, based on the test given by the researcher. And the dependent variable, reading comprehension, is done by the test. The data collection technique that has been done to get the data of reading habit and attitudes and reading comprehension variables are by asking the respondents to answer the question that has been asked by the researcher. The respondents' answers are being scored based on the scoring rule.

In this research there are three variables consist of two independent variables and one dependent variable.

1) Reading Habit Instrument

The instrument test was carried out for same population member, but they do not include a sample member, where in this research, there are only 30 students. A test type was carried out only for validity test of question item and questions of reliability test.

2) Language Attitude Instrument

The questions that are being test trial in this research are 16 questions to 30 students. The question will be measured its validity, difficulties and reliability. The valid question will be used as the instrument for attitudes.

3) Reading Comprehension Instrument

Instrument guideline to measure reading comprehension that 40 questions were selected for test. The questions selected are those which have level difficulty range from easy, medium and difficult and level of discriminating power range from very good, good, and medium. The questions that are being tested trial in this research are 40 questions to 30 students. The question will be used as the instrument for reading comprehension.

Data analysis technique for this research will be done the data technique in distribution table, graphic, histogram for each variable. Beside that each variable will be tabulated and analyzed the center measurement and the mean, mode, and median and the deviation such as the range, variant, standard deviation, the deviate, and curtosis. There are steps for making table frequency distribution and graphic of polygon and histogram.

The normality test is aimed to know whether the data collection results are normal or not. This is will affect to the next process of the statistic analysis, continued by using the pragmatic statistic, while if the data are not normal distributed, then the analysis of non-parametric statistic. Normality test in this research is done by Kolmogorov Smirnov analysis in application computer program for 
statistic, SPSS 20.0. The result for calculation and testing by SPSS 20.0 shown by the table Tests of Normality in column Sig for the testing technique Kolmogorov Smirnov. The criteria of the normality is if the score of sig. KS $>0.05$ so that the data will be stated as a normal distribution.

\section{RESULT AND DISCUSSION}

In order to understand the distribution of data which was obtained from the research results, explanatory analysis was compared. Analysis of explanatory data was carried out to find out the range of data, the average, the median, the mean and the standard deviation. Findings will present the statistic explanation from the result of calculation and testing which was done by computer SPSS 20.0. application program, its analysis and interpretation as well.

\section{The Data Analysis of Reading Habit Variable $\left(X_{1}\right)$}

The score of reading habit variable that was obtained from the respondents has the average of 49.59, with the standard deviation 9.097, the median 48.50, the minimum score 27, and the maximum score 75. Then, in order to describe the existing data range of reading habit variable, it can be seen from the picture below. Based on the picture, it can be seen the description about the high and low of reading habit frequency.

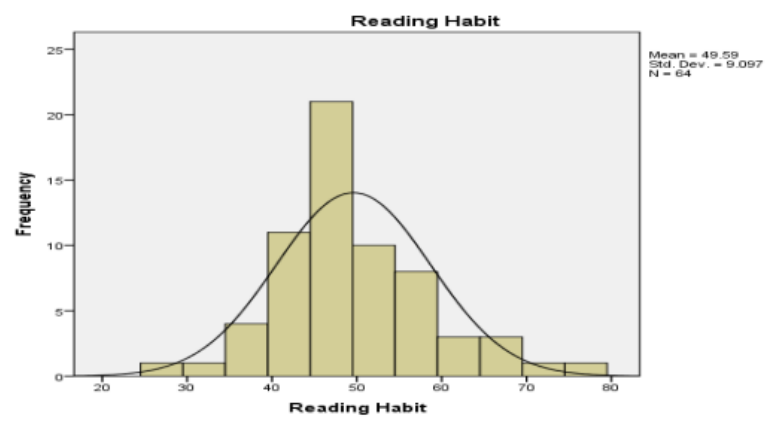

Picture 2. Histogram Data of Reading Habit

From the distribution table, the histogram and polygon frequency, it can be concluded that the data score of reading habit in this research have a normal distribution.

\section{The Data Analysis of Language Attitude $\left(X_{2}\right)$}

The score of language attitude which was obtained from 60 respondents shows the mean is 59.47 with the standard deviation 8.889 , median 61.00 , the minimum score 34 , and the maximum score 80 .

From the description, it can be seen that between the average score and the median is almost same. It shows that the data score of language attitude from this research is quite representative. In order to describe the existing data range clearly of the students' language attitude variable, it can be seen from the picture below. Based on the picture, it can be seen the description about the high and low of the students' score language attitude frequency.

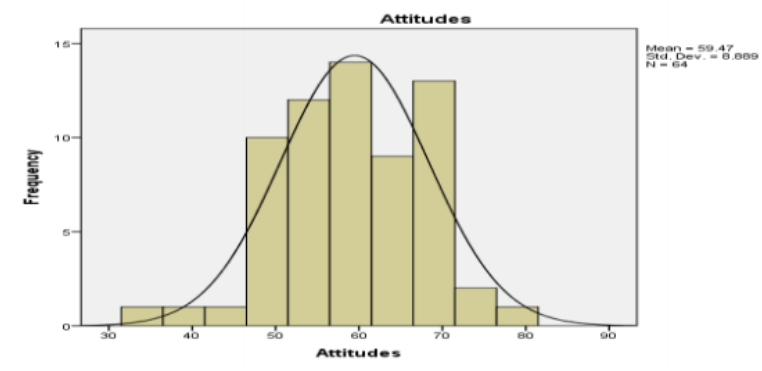

Picture 3. Histogram Data of Language Attitude 
From the distribution table, the histogram and polygon frequency, it can be concluded that the data scores of language attitude in this research have a normal distribution.

\section{The Data Analysis of Reading Comprehension (Y)}

The score of reading comprehension data that was obtained from respondents has the mean 14.33 with the standard deviation 2.488, median 14.00 the minimum score 8, and the maximum score 20. In order to describe the existing data range of reading comprehension variable, it can be seen from then picture below:

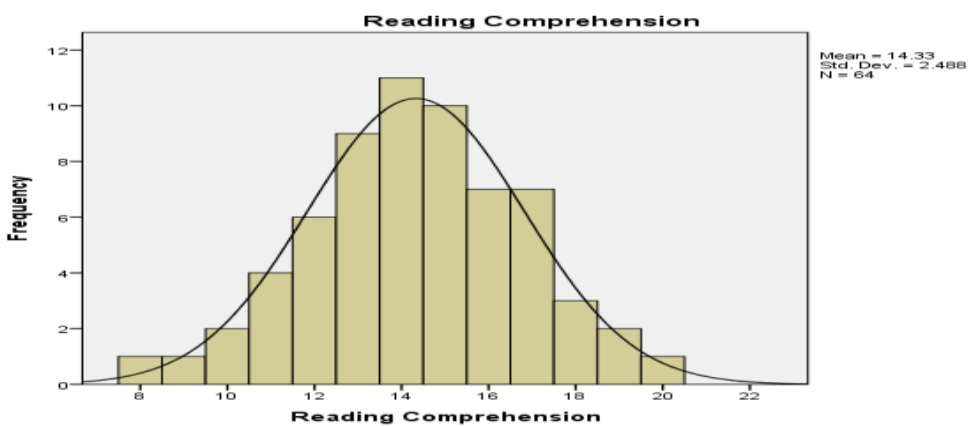

Picture 4. Histogram Data of Reading Comprehensi

From the distribution table, the histogram and polygon frequency, it can be concluded that the data scores of reading comprehension in this research have a normal distribution.

\section{Testing of Data Analysis Requirement}

Testing of analysis data requirement carried out in this research was the normality test and the partial regression linearity line between the independent variables and the pendent variable.

1) The Multicollinearity Data Test

The purposes of The Multicollinearity Data Test is to know the the perfect correlation between independent variables. One step to know how can we found the multicollinearity is to see tolerance or Variance Inflation Factor (VIF). If tolerance $<0.1$ or score of VIF $>10$, so it is multicollinearity. The next rules is if score of TOL and VIF approach digit one so the regression analysis told there is no multicollinearity. The result of multicollinearity test is on the following table and there is no multicollinearity.

Table 1. The Result of Multicollinearity Test

\begin{tabular}{|c|c|c|c|}
\hline \multicolumn{4}{|c|}{ Coefficients $^{a}$} \\
\hline & \multirow[t]{2}{*}{ Model } & \multicolumn{2}{|c|}{ Collinearity Statistics } \\
\hline & & Tolerance & VIF \\
\hline \multicolumn{4}{|c|}{ (Constant) } \\
\hline 1 & Reading Habit & .698 & 1.432 \\
\hline & Attitudes & .698 & 1.432 \\
\hline
\end{tabular}

2) The Heteroscedatisity Test

We can detect heterocedasity with description the curve with a diagram disperse between Z-RESID as $\mathrm{Y}$ with prediction or $\mathrm{Y}$ (Y-Pred) as $\mathrm{X}$. On the picture is describe the score of Z-RESID how much the score Z_PRED. Based on the analysis, it shows that the data is homoscedastisity. So there is no heteroscedasity. 


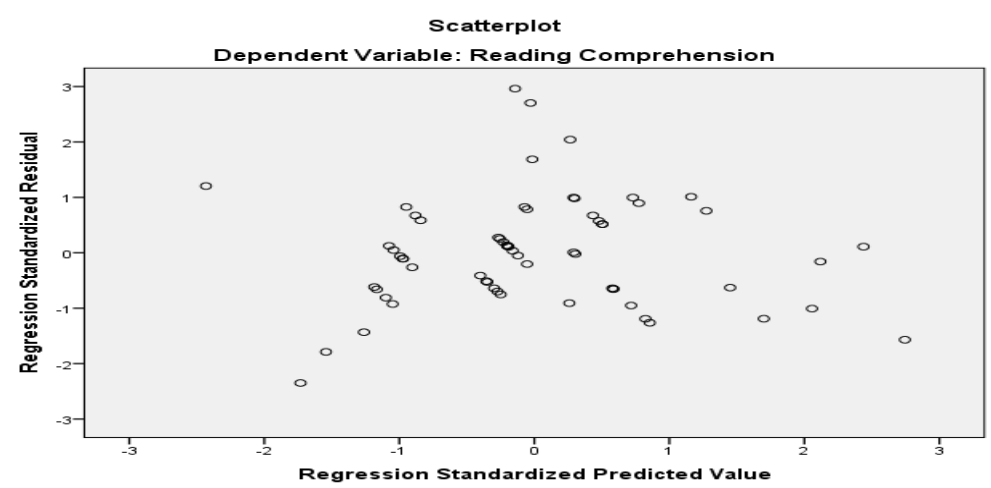

Picture 5. The Result of Heteroscedatisity test

\section{3) The Normality Data Test}

The normality data test of each sample was done the following hypothesis:

$$
\begin{aligned}
& H_{o}=\text { data of the sample which has a normal distribution } \\
& H_{1}=\text { data of the sample which does not have a normal distribution }
\end{aligned}
$$

The calculation was carried out by computer through the application of SPSS 20. Based on the program, the criteria of the normality data is "if $p$ value (sig.) $>0.05$ so $\boldsymbol{H}_{\boldsymbol{o}}$ is accepted", it means that the sample of data has a normal distribution. The score of $p$ value (sig.) is the number that exists in a sig. column inside the result/output table of the normality test from SPSS program. In this case a Kolmogorov-Smirnov method is used. The result can be seen in the following table.

Table 2. The Result of Normality Test

One-Sample Kolmogorov-Smirnov Test

\begin{tabular}{clccc}
\hline & & $\begin{array}{c}\text { Reading } \\
\text { Habit }\end{array}$ & Attitudes & $\begin{array}{c}\text { Reading } \\
\text { Comprehension }\end{array}$ \\
\hline \multirow{2}{*}{$\mathrm{N}$} & \multicolumn{1}{c}{64} & 64 & 64 \\
\cline { 2 - 5 } & Mean & 49.59 & 59.47 & 14.33 \\
\hline Normal Parameters & $\begin{array}{l}\text { Std } \\
\text { Deviation }\end{array}$ & 9.097 & 8.889 & 2.488 \\
& Absolute & .122 & .124 & .088 \\
\cline { 2 - 5 } & Positive & .120 & .073 & .084 \\
\cline { 2 - 5 } $\begin{array}{c}\text { Most Extreme } \\
\text { Differences }\end{array}$ & Negative & -.122 & -.124 & -.088 \\
\hline Kolmogorov-Smirnov Z & & .977 & .990 & .705 \\
\hline Asymp. Sig. (2-tailed) & & .295 & .281 & .702 \\
\hline
\end{tabular}

a. Test distribution is normal

b. Calculated from data

From the above table, it can be seen that sig. column of Kolmogorov-Smirnov method for all samples are more than $0.05(>0.05)$, so $\boldsymbol{H}_{\boldsymbol{o}}$ is accepted. In order words, that the data of all samples in this research has a normal distribution. To strengthen the test result, the Normal Q-Q Plot graphic is presented for every sample, Histogram of Standard Error Normality, the Normality P-P Plot Standard Error Graphic. 


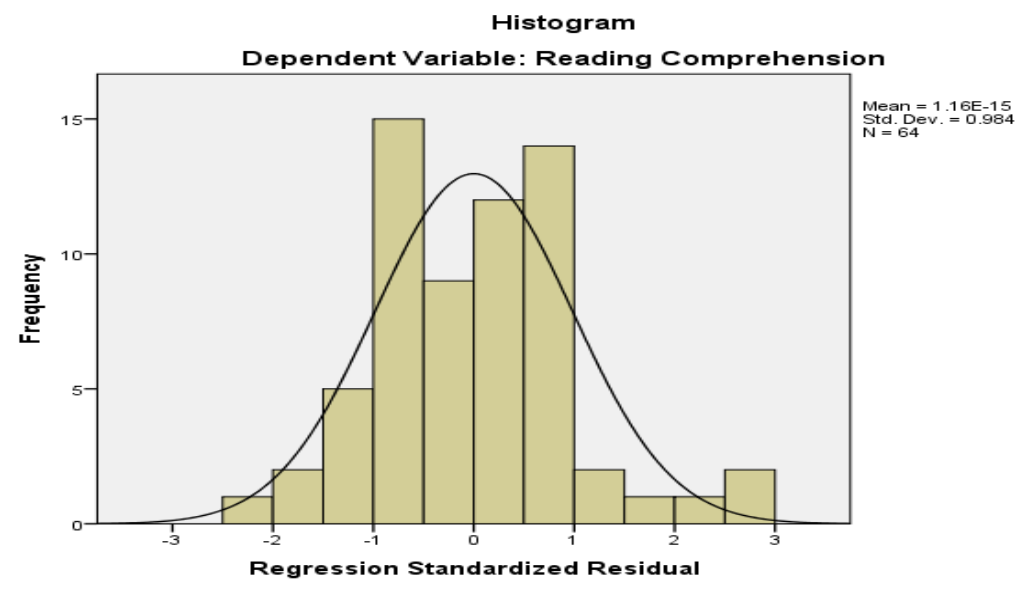

Picture 6. Histogram of Standard Error Normality

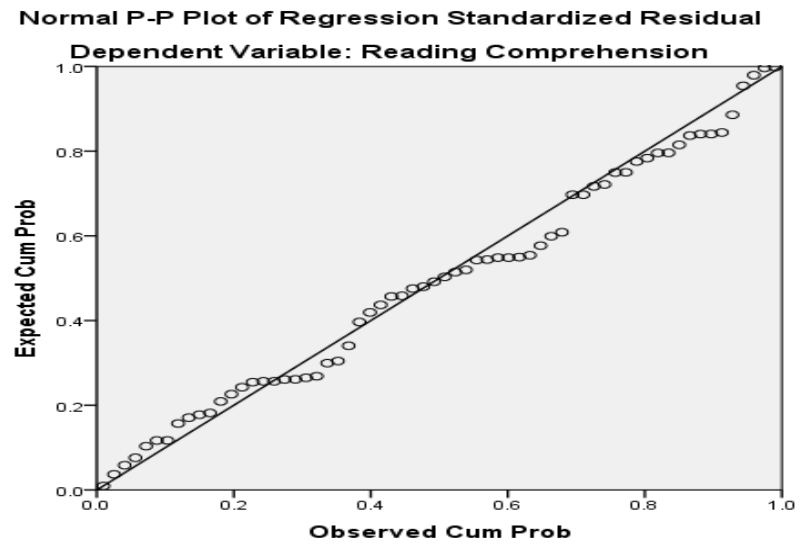

Picture 7. The Graphic of Normality P-P Plot Standard Error

4) The Linearity of Regression Line Test

The linearity test in this research uses the following hypothesis:

$$
\begin{aligned}
& H_{o}=\text { the relation of regression line between variable } \mathrm{X} \text { and variable } \mathrm{Y} \text { linear } \\
& H_{1}=\text { the relation of regression line between variable } \mathrm{X} \text { and variable } \mathrm{Y} \text { not linear }
\end{aligned}
$$

The calculation was carried out by computer through the application SPSS 20.0 program. Based on the program, the criteria of linearity data is "if Sig. $>0.05$, so $H_{o}$ is accepted", it means that regression line is linear. The score of Sig. is the number that exists in the column of Sig. line Deviation from Linearity in ANOVA table, the calculation result of regression line linearity by SPSS program.

\section{Hypothesis Test}

The result of calculating and the test can be seen on the following tables:

Table 3. Model Summary: R and R Squared

\begin{tabular}{ccccc}
\hline Model & $\mathbf{R}$ & R Square & $\begin{array}{r}\text { Adjusted } \\
\text { R Square }\end{array}$ & $\begin{array}{c}\text { Std. Error of } \\
\text { the Estimate }\end{array}$ \\
\hline 1 & $.916^{\mathrm{a}}$ & .840 & .835 & 1.012 \\
\hline a.Predictors: (Constant), Attitudes, Reading Habit \\
\hline
\end{tabular}


Table 4. Analysis of Variance the Impact of Significant Independent Variable and the Impact of Dependent Variable

ANOVA

\begin{tabular}{|c|c|c|c|c|c|c|}
\hline & Model & $\begin{array}{c}\text { Sum of } \\
\text { Squares }\end{array}$ & Df & $\begin{array}{l}\text { Mean } \\
\text { Square }\end{array}$ & $\mathbf{F}$ & Sig \\
\hline & Regression & 327.659 & 2 & 163.829 & 160.024 & $.000^{\mathrm{b}}$ \\
\hline \multirow[t]{2}{*}{1} & Residual & 62.451 & 61 & 1.024 & & \\
\hline & Total & 390.109 & 63 & & & \\
\hline
\end{tabular}

a. Dependent variable: Reading Comprehension

b. Predictors: (Constant), Attitudes, Reading Habit

Table 5. Coefficient Regression and Significant Test

Coefficients ${ }^{\mathrm{a}}$

\begin{tabular}{lcccccc}
\hline \multirow{2}{*}{ Model } & \multicolumn{2}{c}{ Unstandardized Coefficients } & Standardized Coefficients & & \\
\cline { 2 - 7 } & & B & Std. Error & Beta & T & Sig. \\
\hline & (Constant) & 1.432 & .904 & & 1.585 & .118 \\
\hline 1 & Reading Habit & .243 & .017 & .887 & 14.468 & .000 \\
\hline & Attitudes & .015 & .017 & .052 & 1.846 & .040 \\
\hline
\end{tabular}

Dependent Variable: Reading Comprehension

1) The Impact of Reading Habit and Language Attitude towards Students' Reading Comprehension

From the data, after the data collection analysis which has been carried out, it is obtained the correlation coefficient and the coefficient determination. After the test carried out by SPSS program, it was proved that the correlation coefficient was significant. It means that there are significant impacts of independent variable of $X_{1}$ (reading habit) and $X_{2}$ (language attitude) towards a dependent variable $Y$ (reading comprehension).

After having been tested, the regression linearity using SPSS program, it was obtained that the regression line is linear. From the significance test of regression coefficient also using SPSS program, it was obtained that the regression coefficient is significant. It really means that there is a positive impacts of independent variable $X_{1}$ (reading habit) and $X_{2}$ (language attitude) towards dependent variable $\mathrm{Y}$ (reading comprehension).

2) The Impact of Reading Habit towards Student's Reading Comprehension

From the hypothesis test, it is obtained that the score of Sig. $=0.000$ and $\boldsymbol{t}_{\text {test }}=14.468$; so $\boldsymbol{H}_{\boldsymbol{o}}$ is rejected, it means that there is a significant impact of independent variable $X_{1}$ (reading habit) towards dependent variable $\mathrm{Y}$ (reading comprehension).

3) The Impact of Language Attitudes towards Student's Reading Comprehension

From the hypothesis test, it is obtained that the score of Sig. $=0.000$ and $\boldsymbol{t}_{\text {test }}=1.846$; so $\boldsymbol{H}_{\boldsymbol{o}}$ is rejected, it means that there is a significant impact of independent variable $X_{2}$ (language attitude) towards dependent variable $\mathrm{Y}$ (reading comprehension).

\section{CONCLUSIONS}

Reading habit has a positive and significant impact towards the students' reading comprehension. It is therefore, the researcher suggests that all teachers should encourage their students to read every day. By giving great motivation to students to read will give impacts to their language skills. And language attitudes have positive and significant impacts towards the students' reading comprehension. It is therefore, these attitudes influence students' willingness to involve them in reading lessons and related activities. Specifically related to language, it is defined as expressions of positive or negative feelings towards a language which may reflect impression of linguistic 
difficulty or simplicity, ease or difficulty of learning, degree of importance, elegance, social status, etc. Next, the variables of reading habit and language attitudes have positive and significant impacts toward reading comprehension. It is therefore, the role of teacher to motivate and encourage students to make reading as their habit, and to practice and develop their attitudes. And, of course, those things will impact to the students' achievement. Due to the result, it can be inferred that there is an impact of reading habit towards students' reading comprehension (Sig. $=0.000$ and $\boldsymbol{t}_{\text {test }}=14.648$; while $\boldsymbol{t}_{\text {table }}=1.669$ ). There is an effect of language attitude towards students' reading comprehension (Sig. $=0.040$ and $\boldsymbol{t}_{\text {test }}=0.846$; while $\boldsymbol{t}_{\text {table }}=1.669$ ). There are impacts of reading habit and language attitudes towards students' reading comprehension, the score of Sig. $=0.000<0.05$ and $F_{\text {test }}=160.024$; while $F_{\text {table }}=3.148$, so $H_{o}$ is rejected, it means that the regression coefficient is significant.

\section{REFERENCES}

Alderson, 1. C. (2003). Assessing Reading. Cambridge: Cambridge University Press.

Alexander, J. E. (1998). Teaching Reading. London: Scott, Foresman and Company.

Al Qur'an. (1998). Report of the Sixth International lslamic Education Conference. Retrieved February 2008 from, http://www.iberr.org/english.htm

Argungu, D. M. (1996). English Muslims and Islamisation: Between Needs and Deeds. Proceedings from the International Conference on English and lslam: Creatiae Encounters 1996, (pp. 331347). Departrnent of English Language and Literature, International Islamic University Malaysia.

Brantmeier, C. (2006). Toward A Multicomponent Model of Interest and L? Reading: Sources of Interest, Perceived Situational Interest, and Comprehension. Reading in a Foreign Language Journal. 18(2).

Brown, H. D. (2005). English Language Teaching in the "Post-Method" Era: toward Better Diagnosis, Treatment, and Assessment. In I. C. Richards and W. A. Renandya (Eds.), Methodology in Language Teaching: An Anthology of Current Practice. Cambridge: Cambridge University Press.

Cahyono, B. Y. and Widiati, U. (Eds.). (2004). The Tapestry of English Language Teaching and Learning in Indonesia. Malang: State University of Malang Press.

Goodman, Y. (1976). Reading: Language and Psycholinguistic Bases. In P. Lamb and R. Arnold (Eds.), Reading: Foundations and Instructional Strategies. Belmont: Wadsworth Publishing Company, Inc.

Grabe, W. and Stoller, L.F. (2001). Reading for Academic Purposes: Guidelines for the ESL/ EFL Teachers. In M. Celce-Murcia (Ed.), Teaching English as A Second or Foreign Language. Boston: Heinle \& Heinle Publishers.

Hare, A.S. (1996). Pragmatics and Ideology in Approaching Academic Texts. Proceedings from the International Conference on English and Islam: Creation Encounters. (pp. 369-375) Department of English Language and Literature, International Islamic University Malaysia.

Haris, A. J. and Sipay, E. R. (1980). How to Increase Reading Ability: A Guide to A Developmental and Remedial Methods. New York: Longman.

Hutchinson, T. and Waters, A. (2001). English for Specific Purpose. Cambridge: Cambridge University Press.

Iskandarwassid and Sunendar, D. (2008). Strategi Pembelajaran Bahasa. Bandung: PT. Remaja Rosda Karya.

Jazadi,I. (2003). Mandated English Teaching Materials and Their lmplications to Teaching and Learning: The Case of Indonesia. In W. A. Renandya (Ed.), Methodology and Materials Design in 
Language Teaching: Current Perceptions and Their Implications. Singapore: SEAMEO Regional Language Centre.

Johnson, E. B. (2007). Contextual Teaching and Leariing (Indonesian Version). Bandung: Penerbit MLC. Procter, M. (2001). Measuring Attitudes. In N. Gilbert (Ed.), Researching Social Life. London: SAGE. Richards, J.C., Platt I., and Platt, H. (1992). Longman Dictionary of Longman: Teaching and Applied Linguistics. Essex: Longman Group UK Limited.

Richards, J. C. (2002). Curriculum Development in Language Teaching: Cambridge: Cambridge University Press.

Wallace, C. (1992). Reading. Oxford: Oxford University Press. 